Article

\title{
An Investigation of Non-Metallic Inclusions in Different Ferroalloys using Electrolytic Extraction
}

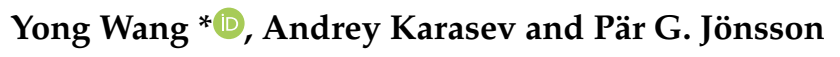 \\ Department of Materials Science and Engineering, KTH Royal Institute of Technology, Brinellvägen 23, \\ 10044 Stockholm, Sweden; karasev@kth.se (A.K.); parj@kth.se (P.G.J.) \\ * Correspondence: yongwang@kth.se; Tel.: +46-(0)72-927-6537
}

Received: 16 May 2019; Accepted: 11 June 2019; Published: 15 June 2019

\begin{abstract}
Ferroalloys are integral constituents of the steelmaking process, since non-metallic inclusions (NMIs) from ferroalloys significantly influence the transformation of inclusions present in liquid steel or they are directly involved in casted steel. In this study, the characteristics of inclusions (such as the number, morphology, size, and composition) in different industrial ferroalloys (FeV, FeMo, FeB, and $\mathrm{FeCr}$ ) were investigated using the electrolytic extraction (EE) technique. After extraction from the ferroalloy samples and filtration of the solution, the inclusions were investigated on a film filter. The three-dimensional (3D) investigations were conducted using a scanning electron microscopy in combination with energy dispersive spectroscopy (SEM-EDS). The characteristics of inclusions observed in the ferroalloys were compared with previous results and discussed with respect to their possible behaviors in the melt and their effects on the quality of the cast steels. The particle size distributions and floatation distances were plotted for the main inclusion types. The results showed that the most harmful inclusions in the ferroalloys investigated are the following: pure $\mathrm{Al}_{2} \mathrm{O}_{3}$ and high $\mathrm{Al}_{2} \mathrm{O}_{3}$-containing inclusions in $\mathrm{FeV}$ alloys; pure $\mathrm{SiO}_{2}$ and high $\mathrm{SiO}_{2}$-containing inclusions in $\mathrm{FeMo}$ alloys; $\mathrm{Al}_{2} \mathrm{O}_{3}$ and $\mathrm{SiO}_{2}$-containing inclusions in $\mathrm{FeB}$ alloys; and $\mathrm{MnO}-\mathrm{Cr}_{2} \mathrm{O}_{3}, \mathrm{Al}_{2} \mathrm{O}_{3}$, and $\mathrm{Cr}_{2} \mathrm{O}_{3}$-based inclusions in $\mathrm{FeCr}$ alloys.
\end{abstract}

Keywords: ferroalloy; non-metallic inclusions; electrolytic extraction; steel quality

\section{Introduction}

Since the cleanliness of steel largely depends on the secondary refining process, one of its main aims is to control the non-metallic inclusion (NMI) contents in steel. In order to improve the cleanliness of steel, it is important to locate the origin of the NMIs and to control them. The main origin of the NMIs is the added materials, including ferroalloys, which are indispensable materials for deoxidation and alloying of different steel grades, used to achieve the desired chemical and physical properties. Therefore, these materials greatly influence the steel quality and the economics of steelmaking. With regard to the ferroalloy production processes, it is known [1] that impurities like $\mathrm{Ca}, \mathrm{S}, \mathrm{Al}$, and $\mathrm{O}$ are inevitable in ferroalloys. As a result, the major alloying elements, as well as the impurities after the additions of ferroalloys in the melt, form new endogenous NMIs as a result of chemical reactions between elements in the ferroalloys and the liquid steels. Moreover, there can be an inadvertent entry of exogenous inclusions present in ferroalloys to the molten steel. This is especially important when ferroalloys are added during the late stage of the ladle metallurgy process. The requirement for steel cleanliness continues to increase, and therefore the NMIs from ferroalloys are studied in greater depth. In addition, in order to meet the composition requirements without increasing the refining time, high-purity ferroalloys are needed.

The cleanliness of ferroalloys and the effect of impurities in different ferroalloys on the final steel quality are important topics for the production of alloyed clean steels and are also areas where 
research is needed. Some researchers have studied the NMIs in different kinds of ferroalloys, such as FeSi [2-5], FeTi [2,5-7], FeCr [3,6,8], SiMn [2,4], and FeMn [5,9,10]. These ferroalloys are well known as the principle ferroalloys considering their large consumption in the steelmaking process. However, the most harmful inclusions have not been discussed in previous papers, which is one of the most concerning problems for steelmaking workers. In recent years, efficient techniques for steel microalloying and modification using ferroalloys containing V, Mo, B, etc. have received a wide acceptance [11]. However, studies that have evaluated the NMIs in these ferroalloys (such as FeV, FeMo and FeB) are rare. One possible reason for this is that these ferroalloys are used in small amounts, and therefore the fraction of NMIs derived from these ferroalloys is small. Although the amount required is small, it is still not negligible in the production of some specific high-purity steel grades.

One common feature is that these ferroalloys are usually added to the melt during the ladle refining for final chemical adjustments. Certainly, the importance of NMIs in these ferroalloys cannot be ignored considering the general increased demand for cleaner steels. Therefore, the cleanliness of these ferroalloys that are used for late additions during ladle refining should be strictly controlled because there is inadequate time for removal of inclusions. Until recently, two-dimensional (2D) methods, acid extraction methods, and electrolytic extraction (EE) methods have been used for investigations of inclusions in ferroalloys [2-10]. The EE method was found to be more accurate with respect to the number and size of inclusions as compared with 2D methods used on polished cross- sections of metal samples. Moreover, the EE method was more appropriate than the acid extraction method because there was less dissolution of inclusions $[2,12,13]$. Therefore, the EE method is applied in the present study.

Using the electrolytic extraction (EE) method, the current study concentrates on investigating the inclusion characteristics in four ferroalloys: (i) FeV, (ii) FeMo, (iii) FeB, and (iv) FeCr. In addition, the NMIs in three FeCr alloys from different companies are compared. The results assist better three-dimensional (3D) investigations of the NMIs present in these ferroalloys.

\section{Materials and Methods}

The investigations of NMIs in this study were carried out using four types of commercial ferroalloys: FeV, FeMo, FeB, and three samples of low carbon FeCr alloys (FeCr-1, FeCr-2, FeCr-3). The typical chemical compositions of these ferroalloys are presented in Table 1 . The residual element content is Fe.

Table 1. Typical compositions of ferroalloys investigated in this study (wt\%).

\begin{tabular}{cccccccccccccc}
\hline Type & V & Mo & B & Cr & Al & Mn & Si & Ca & Mg & C & S & P & O \\
\hline FeV & 80.4 & - & - & - & 3 & - & 1.2 & 0.25 & 0.040 & 0.201 & 0.021 & 0.018 & 0.714 \\
FeMo & - & 66.4 & - & - & 0.01 & $<0.01$ & 0.1 & $<0.01$ & 0.010 & 0.008 & 0.053 & 0.040 & 0.326 \\
FeB & - & - & 20 & - & $<3$ & - & 2 & - & - & 0.050 & 0.010 & 0.015 & 0.050 \\
FeCr-1 & - & - & - & 71.8 & 0.05 & 0.25 & 0.41 & 0.04 & 0.006 & 0.025 & 0.002 & 0.009 & 0.078 \\
\hline
\end{tabular}

The electrolytic extraction (EE) method was applied for the extraction of inclusion particles from the metal matrix. The electrolytic extraction of the ferroalloys was carried out using a 10\% AA (10 v/v\% acetylacetone, $1 \mathrm{w} / \mathrm{v} \%$ tetramethylammonium chloride-methanol) electrolyte. For electrolytic dissolution of the selected ferroalloys, the following parameters were used: electric currents between 60-70 mA, voltages between 4.2-5.0 V, and a charge of 500 coulombs. The total weight of a dissolved ferroalloy during the EE varied from 0.04 to $0.08 \mathrm{~g}$. After extraction, the solution containing inclusions was filtrated through a polycarbonate (PC) membrane film filter (Whatman, Uppsala, Sweden) with an open pore size of $0.4 \mu \mathrm{m}$. Thereafter, the characteristics (morphology, size, number, and composition) of the extracted inclusions were investigated using SEM in combination with EDS. The total observed area of film filter for different samples varied from 3.88 to $7.98 \mathrm{~mm}^{2}$. 
The average size of non-spherical inclusions $\left(d_{V}\right)$ was calculated according to Equation (1):

$$
d_{V}=\frac{L_{\max }+W_{\max }}{2}
$$

where $L_{\max }$ and $W_{\max }$ are the maximum length and width of the investigated inclusion measured by Image-pro plus 6.0 software (Media Cybernetics, Inc., Rockville, MD, USA), respectively.

The number of inclusions per unit volume $\left(N_{V}\right)$ was calculated using Equation (2) [2]:

$$
N_{V}=n \cdot \frac{A_{\text {filter }}}{A_{\text {observed }}} \cdot \frac{\rho_{\text {ferroalloy }}}{W_{\text {dissolved }}}
$$

where $n$ is the number of inclusions in the appropriate size interval, $A_{\text {filter }}$ is the area of the film filter with inclusions $\left(1200 \mathrm{~mm}^{2}\right), A_{\text {observed }}$ is the total observed area on film filter, $\rho_{\text {ferroalloy }}$ is the density of the ferroalloy matrix, and $W_{\text {dissolved }}$ is the dissolved weight of the ferroalloy during extraction.

The floatation velocity of inclusions was estimated using Stokes' law [14], as expressed by Equation (3).

$$
V=\frac{\rho_{F e}-\rho_{N M I}}{18 \mu} \cdot g \cdot d^{2}
$$

where $V$ is the flotation velocity of the inclusion, $g$ is the gravitational acceleration $\left(9.81 \mathrm{~m} \mathrm{~s}^{-2}\right), \mu$ is the dynamic viscosity of liquid steel (0.005 $\mathrm{m}$ Pa s) [14], $d$ is the diameter of the spherical inclusion, and $\rho_{F e}\left(7000 \mathrm{~kg} \mathrm{~m}^{-3}\right)$ and $\rho_{\mathrm{NMI}}$ are the densities of liquid steel and inclusion, respectively. In this study, the $\rho_{N M I}$ values were taken as $3950 \mathrm{~kg} \mathrm{~m}^{-3}$ for $\mathrm{Al}_{2} \mathrm{O}_{3}$ [15], $2648 \mathrm{~kg} \mathrm{~m}^{-3}$ for $\mathrm{SiO}_{2}$ [16], $4930 \mathrm{~kg} \mathrm{~m}^{-3}$ for Cr-Mn-O [17], $2190 \mathrm{~kg} \mathrm{~m}^{-3}$ for Si-Al-Mg-O, $2500 \mathrm{~kg} \mathrm{~m}^{-3}$ for Al-Si-Ca-Mg-O and $2700 \mathrm{~kg} \mathrm{~m}^{-3}$ for $\mathrm{Si}-\mathrm{Al}-\mathrm{O}$ [18]. The different types of inclusions will be described in detail later.

The relationship between the flotation distance $(D)$ of inclusions in the ladle and the flotation time $(t)$ was calculated using Equation (4):

$$
D=V \cdot t
$$

The melting points of inclusions were calculated based on the average compositions in the equilibrium mode using the thermodynamic software Factsage 7.1 (Thermfact Ltd./CRCT, Montreal, Canada and GTT-Technologies, Herzogenrath, Germany).

\section{Results and Discussion}

\subsection{Inclusions in FeV Alloys}

Vanadium is mainly used as an alloying additive in steel to promote the formation of a finer grain size, increased hardenability, and improved wear resistance through the precipitation of its carbides and nitrides $[19,20]$. By far the largest application of vanadium is as a potent microalloying strengthener in high strength low alloy (HSLA) steels $(0.05$ to $0.15 \% \mathrm{~V})$. The tool and die steels are second only to the HSLA grades in terms of vanadium consumption, but they may contain as little as $0.30 \%$ of $\mathrm{V}$ to enable grain size control during the austenitizing operation. Ferrovanadium is usually added to the ladle after deoxidation is completed and it should be added when the ladle is one-quarter to three-quarters full [21].

Typical SEM photographs, size ranges, compositions, and frequencies (in percentage) of different NMIs observed after the $\mathrm{EE}$ of $\mathrm{FeV}$ alloys are shown in Table 2. Overall, six types of inclusions are observed in the FeV alloys, namely, VC, Al-O, Al-Mg-O, Al-Ca-O, Si-O, and Al-Si-O. The type A inclusions are made up of pure vanadium carbides and are further divided into two groups according to their morphology, namely, a rod-like type A1 and a plate-like type A2. The range in size of type A1 inclusions is much larger (about eight times) than that of type A2 inclusions. In addition, the small sizes of type A1 vanadium carbides are found in all of the photographs which means vanadium carbide is the most common inclusion type in $\mathrm{FeV}$ alloys. The type $\mathrm{B}$ inclusions are pure $\mathrm{Al}_{2} \mathrm{O}_{3}$ which are present 
as plate-like type B1 and irregular type B2 inclusions. As shown in Table 2, type B1 (9-77 $\mu \mathrm{m})$ inclusions are much larger than type B2 $(3-18 \mu \mathrm{m})$. Type $\mathrm{C}$ inclusions are irregular calcium aluminates with a high $\mathrm{Al}_{2} \mathrm{O}_{3}$ content (81-92\%), which are solid at steelmaking temperatures. Moreover, type D inclusions are irregularly-shaped spinel inclusions and their range of size is similar to that of type $\mathrm{C}$ inclusions. The type $\mathrm{E}$ and type $\mathrm{F}$ inclusions are irregular pure $\mathrm{SiO}_{2}$ and aluminosilicate inclusions, respectively.

Table 2. Classification of inclusions found in FeV alloys.

\begin{tabular}{|c|c|c|c|c|}
\hline Type & Type A1 & Type A2 & Type B1 & Type B2 \\
\hline \multicolumn{5}{|l|}{$\begin{array}{l}\text { Typical } \\
\text { photo }\end{array}$} \\
\hline$L_{\max }(\mu \mathrm{m})$ & 299 & 21 & 159 & 20 \\
\hline Size range, $d_{V}(\mu \mathrm{m})$ & $2-166$ & $7-18$ & $9-77$ & $3-18$ \\
\hline Average $d_{V}(\mu \mathrm{m})$ & $50.4 \pm 28.2$ & $10.6 \pm 2.7$ & $40.6 \pm 18.2$ & $6.9 \pm 1.7$ \\
\hline $\begin{array}{l}\text { Composition } \\
(\text { mass \%) }\end{array}$ & $\sim 100 \% \mathrm{VC}$ & $\sim 100 \% \mathrm{VC}$ & $\sim 100 \% \mathrm{Al}_{2} \mathrm{O}_{3}$ & $\sim 100 \% \mathrm{Al}_{2} \mathrm{O}_{3}$ \\
\hline Frequency (\%) & $\mathrm{nc}^{*}$ & $\mathrm{nc}^{*}$ & 25 & 51 \\
\hline Type & Type C & Type D & Type E & Type F \\
\hline \multicolumn{5}{|l|}{$\begin{array}{l}\text { Typical } \\
\text { photo }\end{array}$} \\
\hline$L_{\max }(\mu \mathrm{m})$ & 17 & 15 & 26 & 38 \\
\hline Size range $d_{V}(\mu \mathrm{m})$ & $3-12$ & $3-13$ & $5-22$ & $10-32$ \\
\hline Average $d_{V}(\mu \mathrm{m})$ & $5.9 \pm 1.6$ & $6.7 \pm 2.1$ & $13.4 \pm 3.7$ & $21.6 \pm 4.3$ \\
\hline $\begin{array}{c}\text { Composition (mass } \\
\% \text { ) }\end{array}$ & $\begin{array}{c}81-92 \% \mathrm{Al}_{2} \mathrm{O}_{3} \\
8-19 \% \mathrm{CaO}\end{array}$ & $\begin{array}{c}73-88 \% \mathrm{Al}_{2} \mathrm{O}_{3} \\
12-27 \% \mathrm{MgO}\end{array}$ & $\sim 100 \% \mathrm{SiO}_{2}$ & $\begin{array}{c}45-50 \% \mathrm{Al}_{2} \mathrm{O}_{3} \\
50-55 \% \mathrm{SiO}_{2}\end{array}$ \\
\hline Frequency (\%) & 7 & 10 & 5 & 2 \\
\hline
\end{tabular}

nc*, not considered.

The majority of the different types of oxide inclusions are type B inclusions ( $76 \%)$. In addition, an irregular type $\mathrm{B} 2$ inclusion is the most common $\mathrm{Al}_{2} \mathrm{O}_{3}$ inclusion $(\sim 51 \%)$. This is followed by type $\mathrm{D}$ inclusions $(\sim 10 \%)$, type $\mathrm{C}$ inclusions $(\sim 7 \%)$, and finally type $\mathrm{E}(\sim 5 \%)$ and type $\mathrm{F}$ inclusions $(\sim 2 \%)$. All in all, high melting point inclusions, which consist of pure $\mathrm{Al}_{2} \mathrm{O}_{3}$ (type $\mathrm{B}$ ) and high $\mathrm{Al}_{2} \mathrm{O}_{3}$-containing (type $C$ and type D) inclusions, account for 93\% of the total inclusions. Figure 1 shows the size distributions of type B, C, and D inclusions. We see that the number of type B2 inclusions per unit volume is much larger (about four times) as compared with type $C$ and type $D$ inclusions in the range of size of 1-18 $\mu \mathrm{m}$. Whereas, the size range for type B1 inclusions is much wider as compared with the other types of inclusions. Moreover, the size range is similar for type $\mathrm{C}$ and type $\mathrm{D}$ inclusions and the average size of these two types of inclusions is about $6-7 \mu \mathrm{m}$.

Basically, FeV alloys which contain as much as $80 \mathrm{wt} \%$ vanadium are produced by an aluminothermic reduction. This process differs from the carbon and silicon reduction processes in that the reaction is highly exothermic, which enables a low carbon content in FeV alloys [22]. The low carbon content $(\sim 0.201 \%)$ and high Al content $(\sim 3 \%)$, as shown in Table 1, support this conclusion. The basic raw materials for the production of $\mathrm{FeV}$ alloys are vanadium pentoxide, aluminum powder, iron, or steel scrap and lime. The process is improved with some additions of magnesia, calcium carbide, silicon, or carbon. Therefore, a large amount of $\mathrm{Al}_{2} \mathrm{O}_{3}$ inclusions originate from the high $\mathrm{Al}$ content during the process. In addition, other high $\mathrm{Al}_{2} \mathrm{O}_{3}$-contained inclusions are closely related to the production process. 


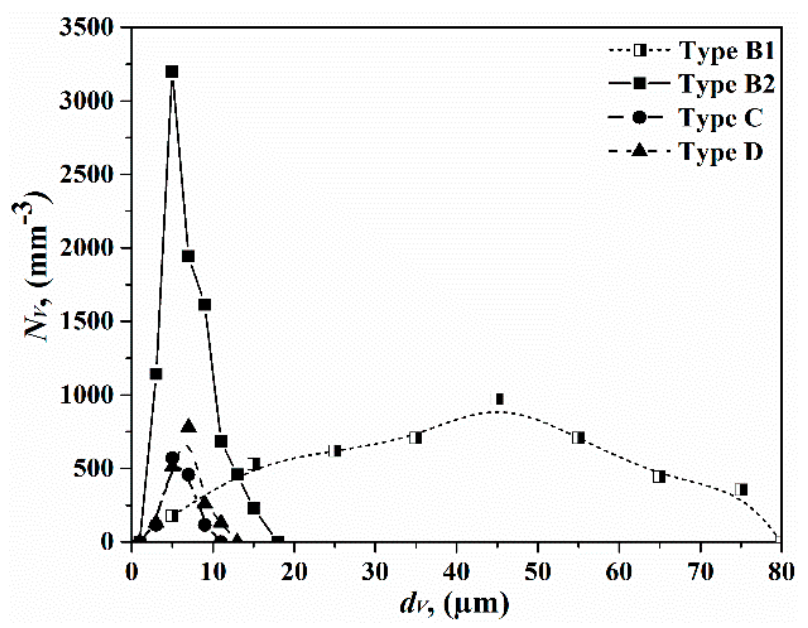

Figure 1. Particle size distributions of type B, type C, and type D inclusions in FeV alloys.

Previous studies [2,5] have reported that impurities in ferroalloys are part of inclusions in the steel. In general, these impurities are made up of the total oxygen, sulfur and phosphorous, trace element impurities and inclusions. A high $\mathrm{O}$ content $(\sim 0.714 \%)$ in $\mathrm{FeV}$ alloys can cause an increase in the total oxygen content of the steel. This indicates that a large number of inclusions are possibly introduced by the addition of these $\mathrm{FeV}$ alloys to a steel melt. The presence of elements such as $\mathrm{Al}(\sim 3 \%)$ and $\mathrm{Ca}(\sim 0.25 \%)$, which have a strong affinity to oxygen, can lead to the formation of complex inclusions depending on the specific conditions, and therefore special attention should be given to elemental control during the production process of $\mathrm{FeV}$ alloys.

Apart from the effect of the $\mathrm{O}$ content and trace elements, the inclusions play a major role in the quality of the steel. The most common inclusion type (VC) may be precipitated during the solidification process of the melted alloy. Most of the presented $\mathrm{V}$ carbides in $\mathrm{FeV}$ are easily dissolved at high temperatures during the steelmaking process.

In principle, the inclusions from $\mathrm{FeV}$ alloys which are larger than a certain size can easily float up after the addition of a FeV alloy to a melt. There are different mechanisms for inclusion removal from liquid steel. Gas and electromagnetic stirring of the melt during the ladle treatment significantly increases the removal rate of non-metallic inclusions due to turbulent collisions and separations of inclusions in the slag by the bulk flow. However, the liquid steel in the ladle is not commonly stirred during transport after the ladle treatment is completed. In this case, the flotation of different non-metallic inclusions in the liquid steel is estimated applying Stoke's law. The calculation results of the flotation distance for $\mathrm{Al}_{2} \mathrm{O}_{3}$ and $\mathrm{SiO}_{2}$ inclusions are shown in Figure 2. Clearly, the flotation distance increases dramatically with an increased diameter of the inclusion. By assuming that the melt depth in the ladle is $2 \mathrm{~m}, \mathrm{Al}_{2} \mathrm{O}_{3}$ inclusions (Figure 2a) larger than $71 \mu \mathrm{m}$ float up during a $20 \mathrm{~min}$ treatment. Therefore, a large amount of $\mathrm{Al}_{2} \mathrm{O}_{3}$ inclusions present in $\mathrm{FeV}$ alloys stay in the steel melt without a forced stirring. It is well known that $\mathrm{Al}_{2} \mathrm{O}_{3}$ inclusions significantly affect the mechanical properties in a negative manner, as well as result in the generation of surface defects [23]. Furthermore, the problem of nozzle clogging in casting operations is frequently related to the presence of solid $\mathrm{Al}_{2} \mathrm{O}_{3}$ inclusions [24]. Similarly, solid $\mathrm{CaO}-\mathrm{Al}_{2} \mathrm{O}_{3}$ (type C) and $\mathrm{MgO}-\mathrm{Al}_{2} \mathrm{O}_{3}$ (type $\mathrm{D}$ ) inclusions are also inherited in the steel. Previous studies $[25,26]$ have reported that solid $\mathrm{CaO}-\mathrm{Al}_{2} \mathrm{O}_{3}$ inclusion particles are subject to agglomeration and form clusters which, in turn, cause microcracks after rolling. In addition, it is well known that spinel inclusions are harmful to steel quality. Moreover, our analyses show, pure $\mathrm{SiO}_{2}$ inclusions (Figure $2 \mathrm{~b}$ ) smaller than $59 \mu \mathrm{m}$ do not float up during the $20 \mathrm{~min}$ treatment. The $\mathrm{SiO}_{2}$ (type $\mathrm{E}$ ) and $\mathrm{Al}_{2} \mathrm{O}_{3}-\mathrm{SiO}_{2}$ (type $\mathrm{F}$ ) inclusions dissolve in steel or react with strong deoxidizers to form complex inclusions [2], which will be discussed in detail in Section 3.2. 


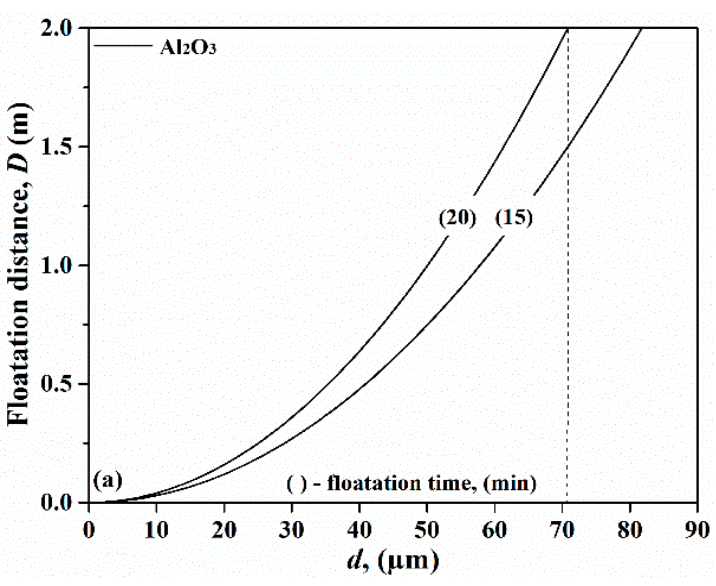

(a)

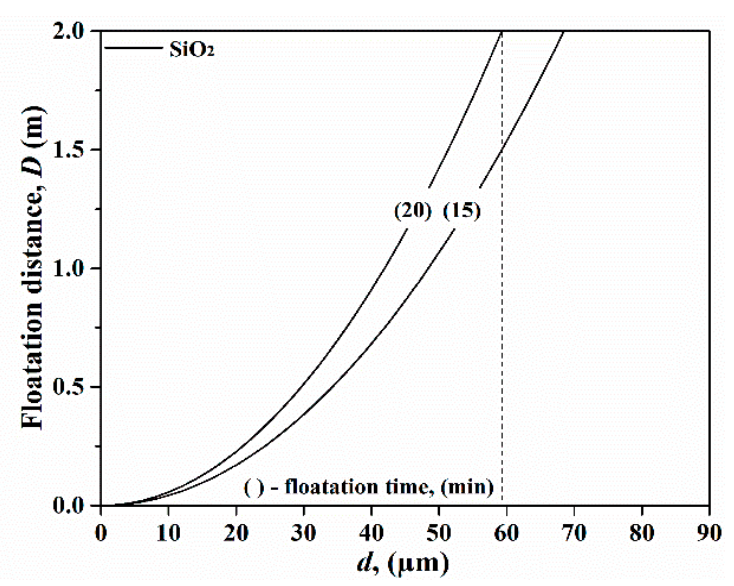

(b)

Figure 2. The floatation distances for $\mathrm{Al}_{2} \mathrm{O}_{3}(\mathbf{a})$ and $\mathrm{SiO}_{2}(\mathbf{b})$ inclusions in liquid steel.

On the basis of our results, we conclud that pure $\mathrm{Al}_{2} \mathrm{O}_{3}$ (type $\mathrm{B}$ ) and high $\mathrm{Al}_{2} \mathrm{O}_{3}$-containing (type $\mathrm{C}$ and $\mathrm{D}$ ) inclusions in $\mathrm{FeV}$ alloys easily stay in the steel and they are harmful to the final steel quality. Therefore, it is essential that all the starting materials in aggregates are pure enough to make a high purity $\mathrm{FeV}$ alloy, since no process has been developed for selectively removing impurities in vanadium alloys in the metallic state.

\subsection{Inclusions in FeMo Alloys}

Molybdenum provides the necessary hardenability in many heat-treatable alloys, such as pressure vessel steels $(0.25 \%$ to $0.9 \%)$ [27], and it also improves the corrosion resistance of stainless steels $(0.3 \%$ to $6 \%$ ) $[28,29]$. In addition, molybdenum promotes the formation of an optimal martensitic matrix in tool steels (up to 3\%). The addition of 5-10\% Mo effectively maximizes the hardness and toughness of high-speed steels [30]. It was reported that Mo in a small proportion $(0.1 \%$ to $0.4 \%)$ exerted a vigorous effect on the hardenability when it was dissolved in austenite HSLA steels [31].

Information about the typical inclusions in the investigated FeMo alloys is shown in Table 3. It illustrates that four types of inclusions were obtained in the FeMo alloys, which are Si-O, Si-Al-Ca-O, $\mathrm{Si}-\mathrm{Al}-\mathrm{O}$, and $\mathrm{Si}-\mathrm{Mg}-\mathrm{O}$ inclusions. Type A inclusions are almost spherically-shaped $\mathrm{SiO}_{2}$ inclusions, which have a larger range of sizes $(5-45 \mu \mathrm{m})$ as compared with the other inclusion types. Moreover, the other three types of inclusions have a high silica content. The irregular type $\mathrm{B}$ inclusions are made up of $\mathrm{SiO}_{2}$, with the presence of $\mathrm{Al}_{2} \mathrm{O}_{3}(15-23 \%)$ and $\mathrm{MgO}(2-6 \%)$. The remaining two types are $\mathrm{SiO}_{2}-\mathrm{Al}_{2} \mathrm{O}_{3}$ and $\mathrm{SiO}_{2}-\mathrm{MgO}$ inclusions containing $23-27 \% \mathrm{Al}_{2} \mathrm{O}_{3}$ (type $\mathrm{C}$ ) and $35-37 \% \mathrm{MgO}$ (type D). The type A inclusions account for approximately half $(\sim 54 \%)$ of the total inclusion content. Thereafter, the presence of the others decreases in the following order: type $\mathrm{B}$, type $\mathrm{C}$, and type $\mathrm{D}$ inclusions. Pande et al. [5] used the acid extraction method to study the acid-insoluble residues of FeMo alloys. They found that the alloys contained spherical $\mathrm{SiO}_{2}-\mathrm{Al}_{2} \mathrm{O}_{3}$ and $\mathrm{CaO}-\mathrm{SiO}_{2}-\mathrm{Al}_{2} \mathrm{O}_{3}$ inclusions, however no information on the composition and size analysis was provided.

Regardless of whether FeMo is produced by Al-reduction, Al-Si-reduction or Si-reduction processes, $\mathrm{FeSi}$ or FeSiAl alloys are charged in the process [29]. The most common mineral of molybdenum in concentrates used for the production of FeMo alloys is molybdenite $\left(\mathrm{MoS}_{2}\right)$. One major impurity in molybdenite is silica, which varies significantly with the ore-dressing degree (from $<0.2 \%$ to $12 \%$ [29]). In addition to the source of raw materials, it is highly likely to be generated from the reaction process between the added $\mathrm{Si}$ and $\mathrm{MoO}_{2}$. In this case, it is reasonable to assume that $\mathrm{SiO}_{2}$ in these raw materials is inherited in FeMo alloys. In addition, silica-containing inclusions may be caused by reactions between $\mathrm{SiO}_{2}$ and $\mathrm{Al}$ and $\mathrm{Mg}$. 
Table 3. Classification of inclusions in FeMo alloys.

\begin{tabular}{|c|c|c|c|c|}
\hline Type & Type A & Type B & Type C & Type D \\
\hline \multicolumn{5}{|l|}{$\begin{array}{l}\text { Typical } \\
\text { photo }\end{array}$} \\
\hline$L_{\max }(\mu \mathrm{m})$ & 53 & 22 & 25 & 18 \\
\hline Size range $d_{V}(\mu \mathrm{m})$ & $5-45$ & $4-15$ & $6-24$ & $9-16$ \\
\hline Average $d_{V}(\mu \mathrm{m})$ & $14.3 \pm 4.3$ & $9.7 \pm 3.1$ & $11.3 \pm 4.3$ & $12.1 \pm 1.8$ \\
\hline Composition (mass \%) & $\sim 100 \% \mathrm{SiO}_{2}$ & $\begin{array}{c}71-83 \% \mathrm{SiO}_{2} \\
15-23 \% \mathrm{Al}_{2} \mathrm{O}_{3} \\
2-6 \% \mathrm{MgO}\end{array}$ & $\begin{array}{c}73-77 \% \mathrm{SiO}_{2} \\
23-27 \% \mathrm{Al}_{2} \mathrm{O}_{3}\end{array}$ & $\begin{array}{l}63-65 \% \mathrm{SiO}_{2} \\
35-37 \% \mathrm{MgC}\end{array}$ \\
\hline Frequency $(\%)$ & 54 & 21 & 17 & 8 \\
\hline
\end{tabular}

A high content of sulfur is observed in FeMo alloys (0.053\%). It is related to oxidated molybdenum concentrates which are used in the initial smelting of FeMo. In addition, the oxygen pick-up in the steel has to be considered during alloying due to the high $\mathrm{O}$ content $(0.326 \%)$, especially for clean steel production. Other trace element impurities should also be considered. These are usually tungsten $(0.3 \%$ to $0.8 \%)$, copper $(<0.5 \%$ for the highest grade and $<2 \%$ for the lowest grade), phosphorus $(<0.05 \%)$, and sulfur $(<0.15 \%)[29]$.

With respect to inclusions, the majority of particles are made up of $\mathrm{SiO}_{2}$ inclusions. Lindborg et al. [32] reported that $\mathrm{SiO}_{2}$ inclusions easily collide within the liquid bath and coalesce to form larger inclusions. According to our result (Figure $2 \mathrm{~b}$ ), pure $\mathrm{SiO}_{2}$ inclusions that are smaller than $59 \mu \mathrm{m}$ do not float up during $20 \mathrm{~min}$ treatment. Therefore, they seriously affect the fatigue properties and impact resistance if they remain in the final product [33]. Perhaps this occurs because they are brittle and have poor deformability due to their large size and high hardness. However, it is unlikely they remain unchanged during the alloying process after the addition of a FeMo alloy.

One common behavior is that the $\mathrm{SiO}_{2}$ inclusions are easily reduced by strong deoxidation elements such as $\mathrm{Al}, \mathrm{Ca}$, Ti, depending on the specific steel grade. Consequently, the formed compounds react with other elements to form complex inclusions. In addition, it is apparent that some local zones of liquid steel around the dissolved $\mathrm{SiO}_{2}$ inclusions have higher concentrations of oxygen and silicon immediately after the addition of the FeMo alloy to the melt. In this case, the phenomenon of a new inclusion type forming outside the $\mathrm{SiO}_{2}$ inclusions also occurs. Therefore, regardless of the harmfulness of $\mathrm{SiO}_{2}$ inclusions themselves, they are also harmful to the final steel quality because they represent an oxygen source.

Figure 3 shows the floatation distance for type $B$ and type $C$ inclusions where inclusions larger than $60 \mu \mathrm{m}$ can be removed from the melt and as a result all type B and C inclusions do not float up from the liquid steel during a 15-20 min treatment time without melt stirring. The melting points of type $\mathrm{B}$ inclusions are about $1183^{\circ} \mathrm{C}$ according to the calculations using FactSage 7.1. In addition, the calculated melting points of type $\mathrm{C}$ and type $\mathrm{D}$ silicate inclusions are $1531{ }^{\circ} \mathrm{C}$ and $1547{ }^{\circ} \mathrm{C}$, respectively. These inclusions will stay liquid when added into the steel, but they belong to high $\mathrm{SiO}_{2}$-containing $(>70 \%)$ inclusions. In this case, they are located outside the low melting area in the $\mathrm{MgO}-\mathrm{Al}_{2} \mathrm{O}_{3}-\mathrm{SiO}_{2}$ phase diagram [34] and further modifications are needed. However, some chemical changes can happen depending on the specific steelmaking conditions. Usually, $\mathrm{Al}_{2} \mathrm{O}_{3}-\mathrm{SiO}_{2}$ system inclusions are the product of first stage deoxidation, which easily change to high alumina-based silicate inclusions [35] or low melting temperature $\mathrm{CaO}-\mathrm{Al}_{2} \mathrm{O}_{3}-\mathrm{SiO}_{2}-\mathrm{MgO}$-based inclusions [36]. Therefore, the effect of inclusions from a FeMo alloy on the final steel quality varies with the steel grade or steel production process. 


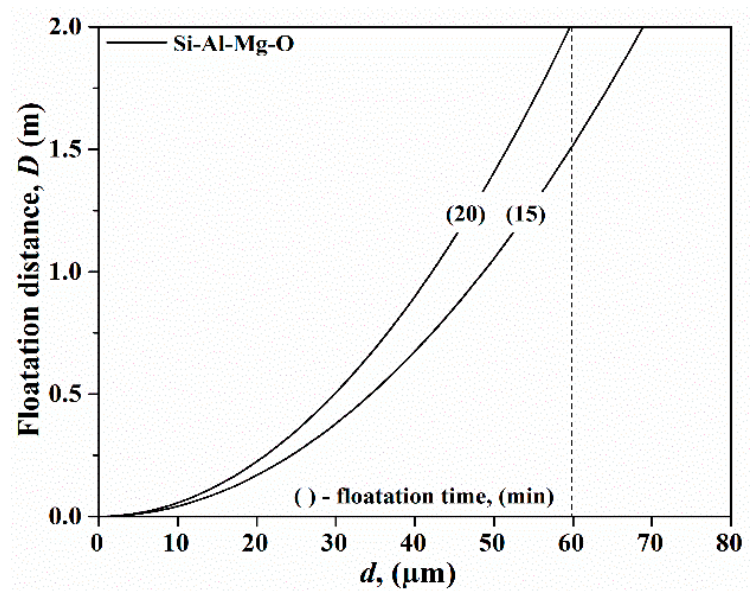

(a)

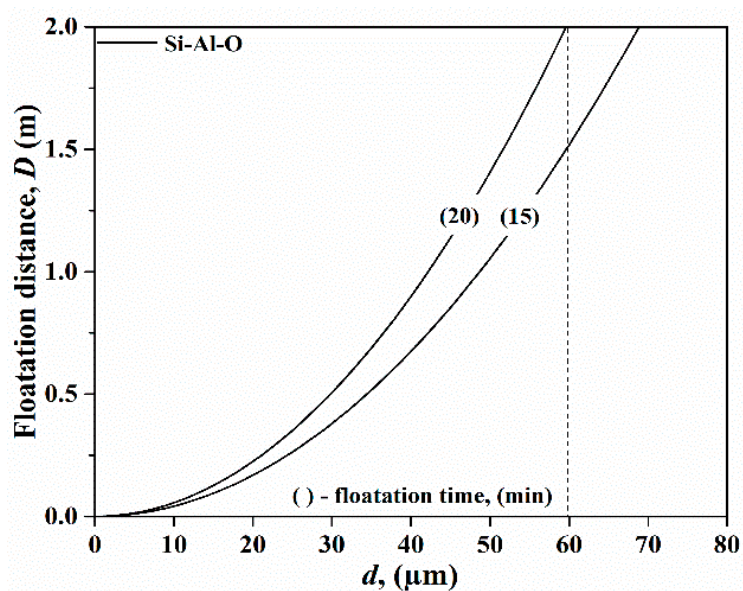

(b)

Figure 3. The floatation distances for Si-Al-Mg-O (a) and Si-Al-O (b) inclusions in liquid steel.

On the basis of our results, we conclud that pure $\mathrm{SiO}_{2}$ (type $\mathrm{A}$ ) and high $\mathrm{SiO}_{2}$-containing (type $\mathrm{B}$ and $\mathrm{C}$ ) inclusions in FeMo alloys are harmful to the final steel quality. According to the Fe-Mo phase diagram [29] such an alloy has a liquidus temperature of over $1800^{\circ} \mathrm{C}$. A high melting point temperature and a high alloy density $\left(9400 \mathrm{~kg} \mathrm{~m}^{-3}\right)$ make it a challenge to add FeMo lumps into molten steel. Thus, FeMo alloys should be added at an early stage to provide sufficient time for the flotation and removal of inclusions.

\subsection{Inclusions in FeB Alloys}

Boron microalloying is one of the most promising trends to increase the qualitative characteristics of steels $(0.0015-0.003 \%$ B), i.e., high hardenability [37], toughness [38], and machinability [39]. It is widely used in high-strength and wear-resistant steels, low alloy corrosion-resistant tube steels, and a number of grades of killed and unkilled carbon steels [11,40-43]. The two alloying elements that prominently assist the occurrence of the austenite-to-ferrite transformation at temperatures below $700{ }^{\circ} \mathrm{C}$ in HSLA steel are molybdenum and boron [44]. Ferroboron does not contain appreciable concentrations of protective elements, therefore, it requires greater care than the proprietary alloys in order to give adequate results. It is normally added after other oxygen and nitrogen scavengers, such as ferrotitanium [45].

The characteristics of inclusions found in the investigated FeB alloys are shown in Table 4, illustrating that four types of inclusions were observed in the FeB alloys based on the composition analysis. These are Al-O, Al-Si-O, Si-O-(Al), and Fe-O inclusions. The majority ( 41\%) of the inclusions are irregular $\mathrm{Al}_{2} \mathrm{O}_{3}$ inclusions (type $\mathrm{A}$ ), which have a size range of 3-15 $\mu \mathrm{m}$. Type $\mathrm{B}$ inclusions are high $\mathrm{SiO}_{2}$ containing aluminosilicate inclusions. The type $\mathrm{C}$ inclusions contain mostly $\mathrm{SiO}_{2}$ with small amounts of $\mathrm{Al}_{2} \mathrm{O}_{3}$ and they have quite a wide size range $(4-28 \mu \mathrm{m})$ as compared with the other inclusion types. The type $\mathrm{D}$ inclusions are spherical iron oxide inclusions, which have a globular shape. With respect to the frequency of the different types of inclusions, type $\mathrm{C}$ inclusions are the second most common (26\%), followed by type B (19\%) and type D (14\%) inclusions. 
Table 4. Classification of inclusions in FeB alloys.

\begin{tabular}{|c|c|c|c|c|c|}
\hline Type & Type A & Type B & Type C & Type D & \\
\hline \multicolumn{6}{|l|}{$\begin{array}{l}\text { Typical } \\
\text { photo }\end{array}$} \\
\hline$L_{\max }(\mu \mathrm{m})$ & 18 & 26 & 33 & 14 & \\
\hline Size range $d_{V}(\mu \mathrm{m})$ & $3-15$ & $3-20$ & $4-28$ & $5-13$ & \\
\hline Average $d_{V}(\mu \mathrm{m})$ & $6.1 \pm 1.9$ & $9.3 \pm 3.8$ & $16.2 \pm 4.8$ & $8.3 \pm 1.3$ & \\
\hline Composition (mass \%) & $\sim 100 \% \mathrm{Al}_{2} \mathrm{O}_{3}$ & $\begin{array}{c}52-79 \% \mathrm{SiO}_{2} \\
21-48 \% \mathrm{Al}_{2} \mathrm{O}_{3}\end{array}$ & $\begin{array}{l}93-99 \% \mathrm{SiO}_{2} \\
1-7 \% \mathrm{Al}_{2} \mathrm{O}_{3}\end{array}$ & $\sim 100 \% \mathrm{FeO}$ & \\
\hline Frequency (\%) & 41 & 19 & 26 & 14 & \\
\hline
\end{tabular}

The particle size distributions of type A, type B, and type $C$ inclusions are shown in Figure 4 and it illustrates that the number of type A inclusions per unit volume is much larger than that of type $B$ inclusions with a size range of 1-12 $\mu \mathrm{m}$. However, the average size of type B inclusions is larger than that of type A inclusions. In addition, the total number of type $C$ inclusions per unit volume is smaller than that of type A inclusions, but they have the largest average size of the three inclusion types.

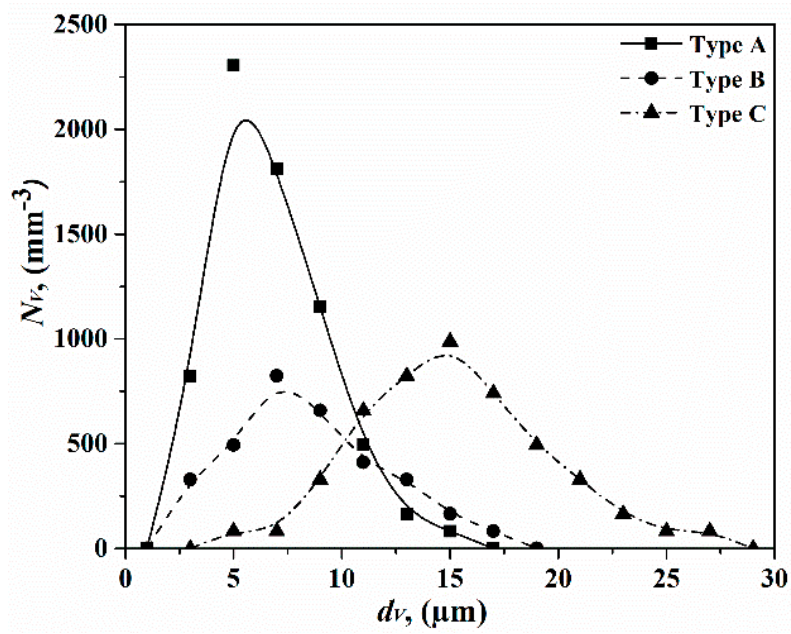

Figure 4. Particle size distributions of type A, type B, and type C inclusions in FeB alloys.

$\mathrm{FeB}$ is processed in electric furnaces by reduction with either aluminum or carbon. The main part of the charge is composed of borate ore $\left(\mathrm{B}_{2} \mathrm{O}_{3}\right)$ and aluminum chips in the aluminum reduction process [42]. In addition, different percentages of iron ore $\left(\mathrm{Fe}_{2} \mathrm{O}_{3}\right)$ and lime are mixed together depending on the ferroboron grade required. The $\mathrm{Al}_{2} \mathrm{O}_{3}$ inclusions and the almost pure $\mathrm{SiO}_{2}$ inclusions are mostly derived from raw materials. As these inclusions have very poor deformability and have shapes containing sharp angles, the behavior of the $\mathrm{Al}_{2} \mathrm{O}_{3}$ and $\mathrm{SiO}_{2}$ inclusions were discussed in the $\mathrm{FeV}$ and FeMo alloys above. During the melting process of alloy production, the difference in the flow of molten metal and the density of the inclusions result in collisions and associations between various types of inclusions [46,47]. Furthermore, this leads to the generation of irregularly-shaped complex inclusions by binding them together or through chemical reactions. The formation of type B inclusions is explained from this point. Moreover, these types of inclusions are similar to type $\mathrm{C}$ inclusions found in FeMo alloys, which are discussed above. The melting point of type $\mathrm{D}$ inclusion is $1369^{\circ} \mathrm{C}$. It is assumed that $\mathrm{FeO}$ has little effect on the cleanliness of steel because it is completely dissolved when added to the steel. However, it does act as a source of oxygen, which promotes the formation of other inclusion types in the melt. 
The influence of boron (B) as an alloying element in steelmaking is associated with the formation of boron nitrides and iron borides [40]. Boron is an exceptionally active element, since it can easily be oxidized and bound in nitrides by small amounts of oxygen and nitrogen concentrations in the steel. Zhuchkov et al. [40] compared the inclusion characteristics of steel micro-alloyed with and without B under laboratory conditions. Their results showed that the total number of inclusions increased in the boron-containing samples. However, the sizes of inclusions were significantly smaller than the samples without boron additions [11,40]. Some researchers [40,41] reported that it is better to introduce $\mathrm{B}$ simultaneously with other alloying elements $(\mathrm{Nb}, \mathrm{V}, \mathrm{Mn}, \mathrm{Si})$ to form strong compounds with $\mathrm{O}$ and $\mathrm{N}$ in steel to prevent their interaction with boron. In addition, FeB alloys are usually added during the final stage of well-deoxidized steel to get an optimized alloying result [42]. From this point of view, inclusions (such as $\mathrm{Al}_{2} \mathrm{O}_{3}$ and silicates) in $\mathrm{FeB}$ alloys do not have enough time to be removed from the melt. Therefore, these inclusions from the FeB alloys are deleterious to the steel quality.

\subsection{Inclusions in FeCr Alloys}

Chromium is one of the most versatile and widely used alloying elements in many steels and alloys, on account of the special properties chromium imparts to these materials. It is an irreplaceable constituent in all stainless steels (up to $27 \%$ of $\mathrm{Cr}$ ) to provide a basic corrosion resistance [28]. It not only finds applications in stainless steels but it is also used in a range of construction and tool steels. An addition of $1 \% \mathrm{Cr}$ increases the yield strength by approximately $50 \%$ and the toughness by $15 \%$ in heat-treatable engineering steel grades [27]. A high carbon $\mathrm{FeCr}(6-8 \% \mathrm{C})$ remains the most widely used chromium addition for the production of stainless and special alloy steels. However, low carbon $\mathrm{FeCr}$ alloys $(0.01-0.25 \% \mathrm{C})$, once quite common, are now added mostly for final chemical adjustments in the production of steel.

It should be pointed out that composition, number, and size of non-metallic inclusions in the same type of ferroalloys is slightly different due to inhomogeneities of the raw materials and due to differences in the production processes. Typical SEM photographs and compositions of the inclusions observed after electrolytic extraction in three $\mathrm{FeCr}$ alloys are shown in Table 5. It illustrates that six different types of inclusions are present in $\mathrm{FeCr}$ alloys, namely, $\mathrm{Cr}-\mathrm{Mn}-\mathrm{O}, \mathrm{Al}-\mathrm{O}, \mathrm{Al}-\mathrm{Si}-\mathrm{Ca}-\mathrm{Mg}-\mathrm{O}, \mathrm{Cr}-\mathrm{O}$, $\mathrm{Cr}-\mathrm{Si}-\mathrm{Mn}-\mathrm{Al}-\mathrm{O}$, and $\mathrm{Cr}-\mathrm{Mg}-\mathrm{Al}-\mathrm{O}$ inclusions. Type $\mathrm{A}$ inclusions are polyhedral $\mathrm{MnO}_{-} \mathrm{Cr}_{2} \mathrm{O}_{3}$ inclusions and type $\mathrm{B}$ inclusions are almost pure irregular $\mathrm{Al}_{2} \mathrm{O}_{3}$ inclusions. Furthermore, type $\mathrm{C}$ inclusions are lump-like Si-Al-Ca-Mg-O inclusions, which are liquid at steelmaking temperatures due to their low melting points (about $1300-1400{ }^{\circ} \mathrm{C}$ according to the calculations using FactSage 7.1). Type D inclusions are irregularly-shaped pure $\mathrm{Cr}_{2} \mathrm{O}_{3}$ inclusions. Moreover, type $\mathrm{E}$ inclusions are made up of $\mathrm{Cr}_{2} \mathrm{O}_{3}$ with $\mathrm{SiO}_{2}(33-46 \%), \mathrm{MnO}(5-8 \%)$, and $\mathrm{Al}_{2} \mathrm{O}_{3}$ (1-3\%). Finally, type $\mathrm{F}$ inclusions contain $\mathrm{Cr}_{2} \mathrm{O}_{3}$ with $\mathrm{MgO}(18-27 \%)$ and $\mathrm{Al}_{2} \mathrm{O}_{3}(6-26 \%)$.

The percentages and size ranges of oxide inclusions are compared for three $\mathrm{FeCr}$ alloys, as shown in Figure 5. It is clearly seen that $\mathrm{Cr}-\mathrm{Mn}-\mathrm{O}$ (type A), Al-Si-Ca-Mg-O (type C), and Cr-O (type D) inclusions were observed in three $\mathrm{FeCr}$ alloys. Some differences exist between the results observed for the different $\mathrm{FeCr}$ alloys, which means the inclusion characteristics are not exactly the same for the same type of ferroalloy. The $\mathrm{Cr}-\mathrm{Mn}-\mathrm{O}$ (type A) inclusion is the main type of inclusion in $\mathrm{FeCr}-1(44 \%)$ and FerCr-3 (40\%) alloys. However, Al-Si-Ca-Mg-O (type C) inclusion is the most common type in $\mathrm{FeCr}-2(36 \%)$ alloy. The frequency of $\mathrm{Cr}-\mathrm{O}$ (type $\mathrm{D})$ inclusions is similar in the studied alloys (about $12 \%$ ). With respect to the size range of inclusions, $\mathrm{Cr}-\mathrm{Mn}-\mathrm{O}$ (type $\mathrm{A}$ ) inclusions show larger size ranges in the FeCr-1 (3-43 $\mu \mathrm{m})$ alloy as compared with the other two alloys. The sizes of type C and type D inclusions vary in the three different $\mathrm{FeCr}$ alloys. Specifically, larger size values of up to 28-34 $\mu \mathrm{m}$ and 23-37 $\mu \mathrm{m}$ are found for type $C$ and type $D$ inclusions, respectively. In addition to these three types of inclusions, the following other inclusion types were found in three of the alloys: $\mathrm{Al}_{2} \mathrm{O}_{3}$ (type $\mathrm{B}$ ) inclusions in $\mathrm{FeCr}-1$ (25\%) and FeCr-2 (9\%) alloys, Cr-Si-Mn-Al-O (type E) inclusions in FeCr-2 (7\%) and $\mathrm{FeCr}-3$ (18\%) alloys, and Cr-Mg-Al-O (type F) inclusions in FeCr-2 (20\%) and FeCr-3 (10\%) alloys. 
Table 5. Classification of inclusions in FeCr alloys.

\begin{tabular}{|c|c|c|c|}
\hline Type & Type A & Type B & Type C \\
\hline \multicolumn{4}{|l|}{$\begin{array}{l}\text { Typical } \\
\text { photo }\end{array}$} \\
\hline$L_{\max }(\mu \mathrm{m})$ & 60 & 22 & 45 \\
\hline Size range $d_{V}(\mu \mathrm{m})$ & $3-43$ & $5-20$ & $5-37$ \\
\hline $\begin{array}{l}\text { Composition } \\
(\text { mass \%) }\end{array}$ & $\begin{array}{c}70-78 \% \mathrm{Cr}_{2} \mathrm{O}_{3} \\
22-30 \% \mathrm{MnO}\end{array}$ & $\sim 100 \%$ & $\begin{array}{c}35-44 \% \mathrm{Al}_{2} \mathrm{O}_{3} \\
32-41 \% \mathrm{SiO}_{2} \\
11-15 \% \mathrm{CaO} \\
2-6 \% \mathrm{MgO}\end{array}$ \\
\hline Frequency (\%) & $16-44$ & $9-25$ & $17-36$ \\
\hline Type & Type D & Type E & Type F \\
\hline \multicolumn{4}{|l|}{$\begin{array}{l}\text { Typical } \\
\text { photo }\end{array}$} \\
\hline$L_{\max }(\mu \mathrm{m})$ & 37 & 20 & 21 \\
\hline Size range $d_{V}(\mu \mathrm{m})$ & $5-34$ & $5-19$ & 5-17 \\
\hline $\begin{array}{l}\text { Composition } \\
(\text { mass \%) }\end{array}$ & $\sim 100 \% \mathrm{Cr}_{2} \mathrm{O}_{3}$ & $\begin{array}{c}44-56 \% \mathrm{Cr}_{2} \mathrm{O}_{3} \\
33-46 \% \mathrm{SiO}_{2} \\
5-8 \% \mathrm{MnO} \\
1-3 \% \mathrm{Al}_{2} \mathrm{O}_{3}\end{array}$ & $\begin{array}{c}51-76 \% \mathrm{Cr}_{2} \mathrm{O}_{3} \\
18-27 \% \mathrm{MgO} \\
6-26 \% \mathrm{Al}_{2} \mathrm{O}_{3}\end{array}$ \\
\hline Frequency (\%) & $10-14$ & $7-18$ & $10-20$ \\
\hline
\end{tabular}

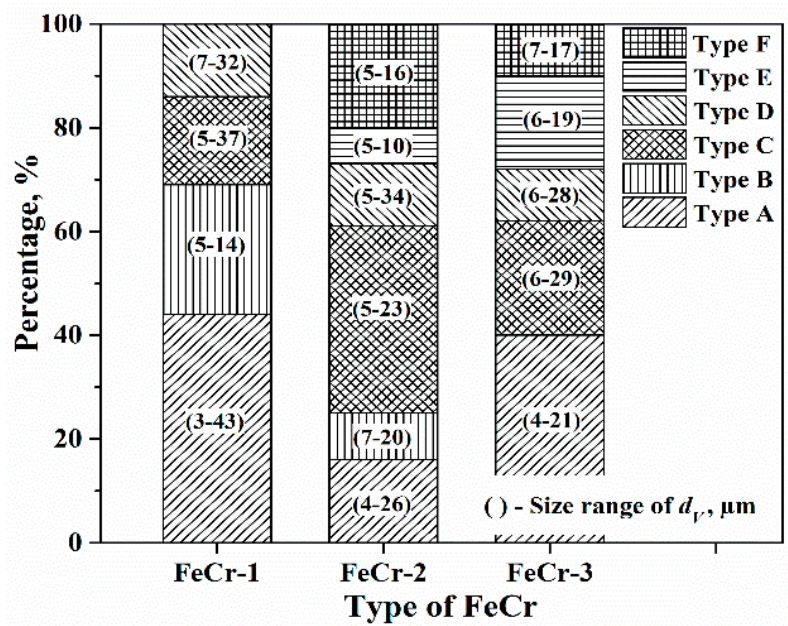

Figure 5. Frequencies and size ranges of different types of inclusions in three different $\mathrm{FeCr}$ alloys.

Type A $\left(\mathrm{MnO}-\mathrm{Cr}_{2} \mathrm{O}_{3}\right)$ inclusions were observed by Vorob'ev [3], but they did not provide detailed information (morphology, size, composition) on the type of inclusion. The particle size distributions of type A inclusions in three $\mathrm{FeCr}$ alloys are shown in Figure 6. The number of type A inclusions per unit volume has the largest value in the $\mathrm{FeCr}-1$ alloy and the smallest value in the $\mathrm{FeCr}-2$ alloy. In addition, type $\mathrm{C}$ and type $\mathrm{D}$ inclusions were also reported in the previous article [8]. The size ranges of type $C(5-37 \mu \mathrm{m})$ and $D$ inclusions $(5-34 \mu \mathrm{m})$ are similar to the reported data, which are 3-28 $\mu \mathrm{m}$ and 6-30 $\mu \mathrm{m}$, respectively. In addition, apart from these, type $\mathrm{B}\left(\mathrm{Al}_{2} \mathrm{O}_{3}\right)$, type $\mathrm{E}(\mathrm{Cr}-\mathrm{Si}-\mathrm{Mn}-\mathrm{Al}-\mathrm{O})$, and type $\mathrm{F}(\mathrm{Cr}-\mathrm{Mg}-\mathrm{Al}-\mathrm{O})$ inclusions have not been reported yet. Moreover, the differences with respect 
to the inclusion types in different $\mathrm{FeCr}$ alloys are closely related to the production processes and raw materials.

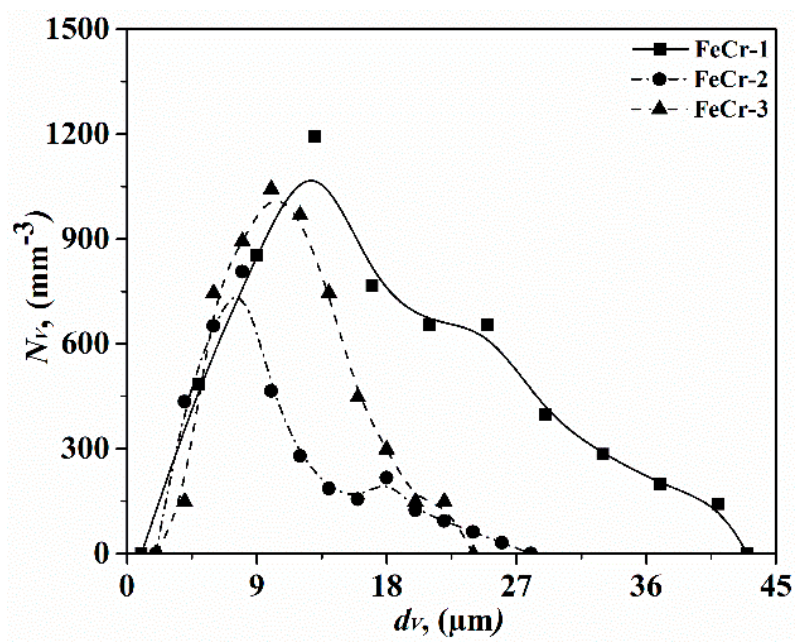

Figure 6. Particle size distributions of type A inclusions in three different FeCr alloys.

The basic raw charge materials for the production of low-carbon $\mathrm{FeCr}$ are $\mathrm{Cr}_{2} \mathrm{O}_{3}, \mathrm{FeSiCr}$, and lime or high-carbon FeCr. Theoretically, the reaction of chromium oxide with aluminum leads to the formation of metallic chromium and aluminum oxide. Type $\mathrm{A}\left(\mathrm{MnO}-\mathrm{Cr}_{2} \mathrm{O}_{3}\right)$ inclusions occasionally lead to poor flushing of the non-metallics [48], which causes nozzle clogging. Moreover, analysis of tensile fracture surfaces indicates a shift of failure initiation sites from $\mathrm{MnCr}_{2} \mathrm{O}_{4}$ phases, which can cause surface cracks [49]. Therefore, the presence of $\mathrm{MnO}-\mathrm{Cr}_{2} \mathrm{O}_{3}$ inclusions in steels might partly originate from the $\mathrm{FeCr}$ alloy.

The effect of type $\mathrm{B}\left(\mathrm{Al}_{2} \mathrm{O}_{3}\right)$ inclusions on the steel quality have been discussed above, and they are considered as harmful inclusions. Type $\mathrm{C}$ (Al-Si-Ca-Mg-O) inclusions are assumed to originate from the slag, which is created during the $\mathrm{FeCr}$ production [8]. They belong to plastic inclusions and stay liquid in the melt. Figure 7 presents the floatation distance of type $\mathrm{A}$ and type $\mathrm{C}$ inclusions. As can be seen, inclusions larger than $87 \mu \mathrm{m}$ and $58 \mu \mathrm{m}$ float up from the ladle to the slag without stirring for type $\mathrm{A}$ and type $\mathrm{C}$ inclusions, respectively. Therefore, most particles inhabit in the steel and stay in it.

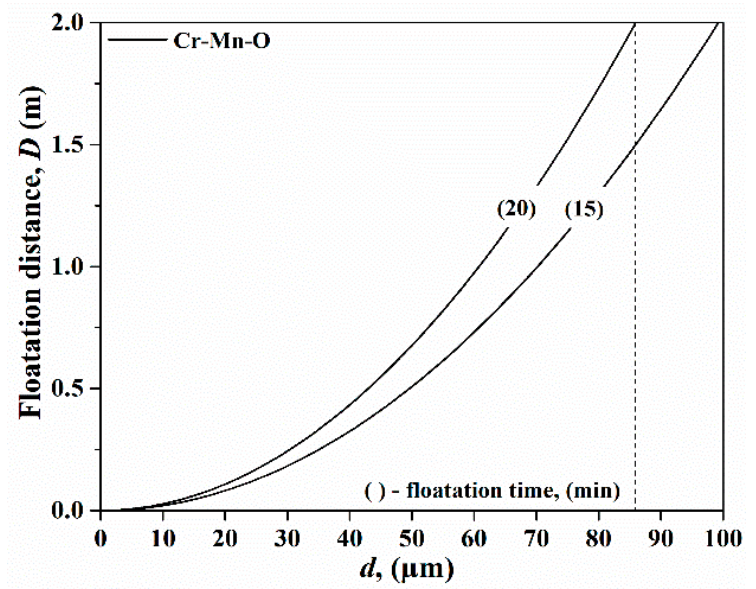

(a)

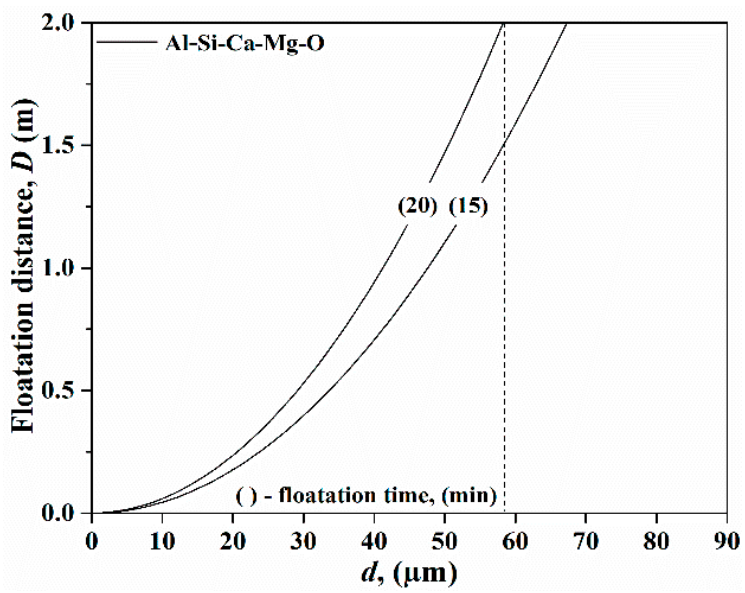

(b)

Figure 7. The floatation distances for $\mathrm{Cr}-\mathrm{Mn}-\mathrm{O}(\mathbf{a})$ and $\mathrm{Al}-\mathrm{Si}-\mathrm{Ca}-\mathrm{Mg}-\mathrm{O}(\mathbf{b})$ inclusions in liquid steel.

The calculated melting point for type A inclusions is about $1583^{\circ} \mathrm{C}$, and the percentage of the liquid phase at steelmaking temperatures of $1600{ }^{\circ} \mathrm{C}$ is about $42 \%$. Similarly, type E and type F 
inclusions have a $26 \%$ and a $24 \%$ liquid phase under the same condition, according to the calculations by Factsage 7.1. The source might be the refractory chromium oxide [3]. Their dissolution is controlled by the rate of mass transfer between a solid and a liquid. In addition, additional research is required to determine whether they dissolve or not after being added to steel. Type $\mathrm{D}\left(\mathrm{Cr}_{2} \mathrm{O}_{3}\right)$ inclusions have a higher melting point (about $2400{ }^{\circ} \mathrm{C}$ ) than the steelmaking temperature. They have an effect on the cleanliness of steel, especially at a late addition just before casting [8]. However, these $\mathrm{Cr}_{2} \mathrm{O}_{3}$-containing inclusions react with $\mathrm{Al}$ and $\mathrm{Ca}$ in steel melt to form new complex inclusions, which depends on the specific steelmaking conditions.

In conclusion, $\mathrm{MnO}-\mathrm{Cr}_{2} \mathrm{O}_{3}$ (type $\mathrm{A}$ ), $\mathrm{Al}_{2} \mathrm{O}_{3}$ (type $\mathrm{B}$ ), and $\mathrm{Cr}_{2} \mathrm{O}_{3}$-based inclusions (type $\mathrm{D}, \mathrm{E}$ and type F) are listed as harmful inclusions in FeCr alloys. Therefore, these inclusions should be given special attention in order to avoid them during the production process.

\subsection{The Influence of Ferroalloy Addition on the Steel Quality}

According to the above discussion and results from previous researchers [2-6,8-10], the factors of ferroalloy affecting final steel quality are summarized, as shown in Figure 8. The sequence of ferroalloy additions is chosen based on its affinity to oxygen to get the optimized alloying result, e.g., FeB alloy. Physical properties are also of great consideration since the density, melting temperature, and lump size affect the melting behavior of the ferroalloys in the melt. The melting point is related to the rate and completeness of assimilation of elements by the alloy. Usually, ferroalloys with a high melting point should be added at an early stage, e.g. FeMo and FeV alloys. The size of the ferroalloy pieces to be added determines the dissolution time of ferroalloys in steel and the method and sequence of addition should be optimized by industrial tests. Elemental impurities in ferroalloy have a large effect on the formation of inclusions in steel, e.g., a high $\mathrm{Al}$ content in $\mathrm{FeV}$ alloy. It is important to know the oxygen, sulfur, and phosphor contents, since they can have a direct influence on the steel cleanliness. In addition, some trace elements such as $\mathrm{Pb}, \mathrm{Sn}, \mathrm{Sb}, \mathrm{Zn}$, and Bi should also be considered since they might have an effect on the final steel properties [6].
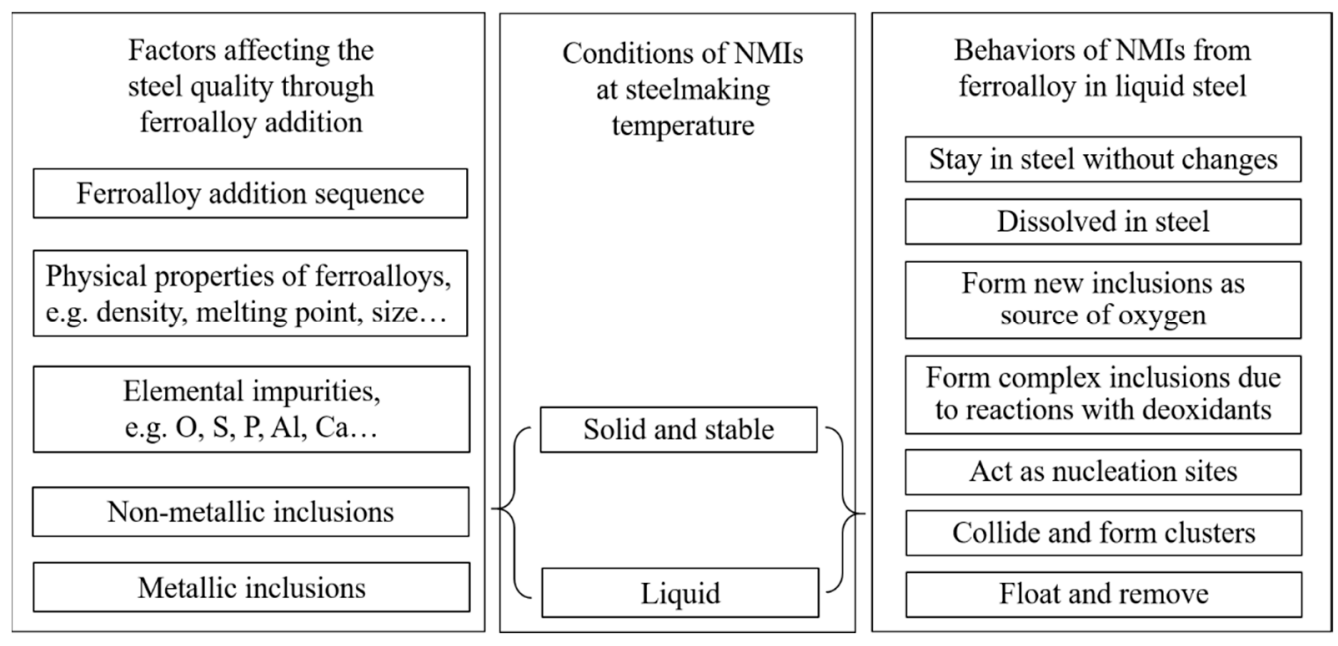

Figure 8. The possible effect of ferroalloy additions on the quality of steel cleanliness.

Overall, the non-metallic inclusions in ferroalloys play a vital role in determining the final steel quality. Apart from flotation and removal of inclusions by slag, the behavior of them in liquid steels is divided into different groups depending on the thermodynamic stability of the inclusions at the specific steelmaking conditions. At the steelmaking temperature, the inclusions from ferroalloy are stable and remain solid or liquid in the steel. Some possible behaviors of these inclusions that occur in steel include the following: (1) they are present in the cast steel without any changes because they are not completely removed during the ladle refining, (2) they dissolve in the steel which introduces new inclusions due to the dissolved elements from the ferroalloys, (3) they are reduced by elements with 
a strong affinity to oxygen or they react with other inclusions to form complex ones, (4) they act as nucleation and growth sites for newly inclusions, (5) they collide with each other and form clusters, (6) they float up and are removed by slag. With respect to the intermetallic inclusions, most of them are assumed to dissolve in the steel. However, some particles, such as a pure $\mathrm{Nb}$ phase, do not melt and should also be considered [2]. Thus, we should consider the changes of all these parameters after the addition of ferroalloys to a steel melt. Further studies are needed to be carried out to understand the contribution of each factor in the future.

\section{Conclusions}

Inclusion characteristics (such as morphology, composition, and size distribution) were analyzed in four commercial ferroalloys using an EE method followed by a SEM-EDS characterization. The information obtained in this study contributes to a better understanding of the influence of inclusions in ferroalloys on later steel quality. On the basis of the obtained results, the following conclusions are made:

(1) The EE method can successfully be applied to investigate the inclusion characteristics in ferroalloys (FeV, FeMo, FeB and FeCr).

(2) The main inclusion types in $\mathrm{FeV}$ alloys are $\mathrm{Al}_{2} \mathrm{O}_{3}$ and vanadium carbides. Especially, pure $\mathrm{Al}_{2} \mathrm{O}_{3}$ and high $\mathrm{Al}_{2} \mathrm{O}_{3}$-containing inclusions are harmful to the final steel quality.

(3) The main inclusion types in FeMo alloys are pure $\mathrm{SiO}_{2}$ inclusions. Especially, pure $\mathrm{SiO}_{2}$ and high $\mathrm{SiO}_{2}$-containing inclusions in FeMo alloys are harmful to the final steel quality.

(4) The main inclusion types in $\mathrm{FeB}$ alloys are $\mathrm{Al}_{2} \mathrm{O}_{3}$ and $\mathrm{SiO}_{2}$-containing inclusions and both are harmful to the final steel quality.

(5) The main inclusion types in $\mathrm{FeCr}$ alloys are $\mathrm{Cr}_{2} \mathrm{O}_{3}-\mathrm{MnO}$ and $\mathrm{Al}_{2} \mathrm{O}_{3}-\mathrm{SiO}_{2}-\mathrm{CaO}-\mathrm{MgO}$ inclusions which are harmful to the final steel quality.

(6) The behavior of different inclusions after the additions of ferroalloys to the molten steel depends on the cleanliness of the ferroalloys as well as the specific steel grades and steelmaking conditions. Thus, optimizations need to be done for each steel grade.

Author Contributions: Conceptualization, A.K. and P.G.J.; formal analysis, Y.W.; investigation, Y.W.; writing — original draft preparation, Y.W.; writing_-review and editing, A.K. and P.G.J.; supervision, A.K. and P.G.J.

Funding: The China Scholarship Council (201700260233) is acknowledged for the financial support of this study.

Conflicts of Interest: The authors declare no conflict of interest.

\section{References}

1. Habashi, F. Handbook of Extractive Metallurgy; Wiley-VCH: New York, NY, USA, 1997.

2. Bi, Y.; Karasev, A.; Jönsson, P.G. Three-dimensional investigations of inclusions in ferroalloys. Steel Res. Int. 2014, 85, 659-669. [CrossRef]

3. Vorob'ev, Y.P. Quantitative phase analysis of exogenous nonmetallic inclusions in steel. Steel Transl. 2008, 38, 69-76. [CrossRef]

4. Franklin, A.G.; Rule, G.; Widdowson, R. Trace elements in ferro-alloy deoxidants and their influence on non-metallic inclusion compositions. In Proceedings of the Vth International Congress on X-Ray Optics and Microanalysis, Tübingen, Germany, 9-14 September 1968; pp. 474-480.

5. Pande, M.M.; Guo, M.; Guo, X.; Geysen, D.; Devisscher, S.; Blanpain, B.; Wollants, P. Ferroalloy quality and steel cleanliness. Ironmak. Steelmak. 2013, 37, 502-511. [CrossRef]

6. Gasik, M.I.; Panchenko, A.I.; Salnikov, A.S. Ferroalloy quality for electric steelmaking with nonmetallic inclusion control. Metall. Min. Indus. 2011, 3, 1-9.

7. Kaushik, P.; Pielet, H.; Yin, H. Inclusion characterisation-Tool for measurement of steel cleanliness and process control: Part 2. Ironmak. Steelmak. 2009, 36, 572-582. [CrossRef]

8. Bi, Y.; Karasev, A.; Jönsson, P.G. Investigations of inclusions in ferrochromium alloys. Ironmak. Steelmak. 2014, 41, 756-762. [CrossRef] 
9. Sjöqvist, T.; Jönsson, P.G.; Grong, Ö. Inclusions in commercial low and medium carbon ferromanganese. Metall. Mater. Trans. A 2001, 32, 1049-1056. [CrossRef]

10. Han, P.W.; Chu, S.J.; Mei, P.; Lin, Y.F. Oxide inclusions in ferromanganese and its influence on the quality of clean steels. J. Iron Steel Res. Int. 2014, 21, 23-27. [CrossRef]

11. Zhuchkov, V.I.; Sychev, A.V.; Babenko, A.A.; Akberdin, A.A.; Kim, A.S. Search for new compositions of boron-containing ferroalloys, their application and development of appropriate production techniques. In Proceedings of the Fourteenth International Ferroalloys Congress, Kiev, Ukraine, 31 May-4 June 2015.

12. Janis, D.; Inoue, R.; Karasev, A.; Jönsson, P.G. Application of different extraction methods for investigation of nonmetallic inclusions and clusters in steels and alloys. Adv. Mater. Sci. Eng. 2014, 7, 1-7. [CrossRef]

13. Inoue, R.; Ueda, S.; Ariyama, T.; Suito, H. Extraction of nonmetallic inclusion particles containing MgO from steel. ISIJ Int. 2011, 51, 2050-2055. [CrossRef]

14. Kellner, H.; Karasev, A.; Sundqvist, O.; Jönsson, P.G. Estimation of Non-Metallic Inclusions in Industrial Ni Based Alloys 825. Steel Res. Int. 2017, 88, 1600024. [CrossRef]

15. Xuan, C.J.; Karasev, A.; Jönsson, P.G. Evaluation of agglomeration mechanisms of non-metallic inclusions and cluster characteristics produced by Ti/Al complex deoxidation in Fe-10mass\% Ni alloy. ISIJ Int. 2016, 56, 1204-1209. [CrossRef]

16. Lide, D.R. CRC Handbook of Chemistry and Physics, 86th ed.; CRC Press: Boca Raton, FL, USA, 2005.

17. Pierre, V.; Karin, C. $\mathrm{MnCr}_{2} \mathrm{O}_{4}$ Crystal Structure: Datasheet from "Pauling File Multinaries Edition-2012" in Springer Materials; Springer: Heidelberg, Germany; Material Phases Data System (MPDS): Vitznau, Switzerland; National Institute for Materials Science (NIMS): Tsukuba, Japan, 2016.

18. Eisenhüttenleute, V.D. Slag Atlas, 2nd ed.; Verlag Stahleisen GmbH: Düsseldorf, Germany, 1995; pp. 318-441.

19. Gao, H.; Zhang, X.L.; Bai, R.G.; Zhong, Z.Y.; Tian, P. Application of different vanadium alloys in steel. In Proceedings of the International Conference on Computer Information Systems and Industrial Applications, Bangkok, Thailand, 28-29 June 2015.

20. Swinbourne, D.R.; Richardson, T.; Cabalteja, F. Understanding ferrovanadium smelting through computational thermodynamics modeling. Min. Proc. Ext. Metall. 2016, 125, 45-55. [CrossRef]

21. Ferroalloys \& Alloying Additives Online Handbook-Vanadium. Available online: http://amgv.com/ vanadiumpage.html (accessed on 8 April 2019).

22. Gasik, M. Technology of Vanadium Ferroalloys. In Handbook of Ferroalloy; Elsevier: Amsterdam, Nederland, 2013; pp. 397-409.

23. Herrera, M.; Castro, F.; Castro, M.; Méndez, M.; Solís, H.; Castellá, A.; Barbaro, M. Modification of $\mathrm{Al}_{2} \mathrm{O}_{3}$ inclusions in medium carbon aluminum killed steels by AlCaFe additions. Ironmak. Steelmak. 2013, 33, 45-51. [CrossRef]

24. Zhang, L.F.; Thomas, B.G. State of the art in evaluation and control of steel cleanliness. ISIJ Int. 2003, 43, 271-291. [CrossRef]

25. Coletti, B.; Blanpain, B.; Vantilt, S.; Sridhar, S. Observation of calcium aluminate inclusions at interfaces between Ca-treated, Al-killed steels and slags. Metall. Mater. Trans. B 2003, 34, 533-538. [CrossRef]

26. Yin, H.B.; Shibata, H.; Emi, T.; Suzuki, M. Characteristics of agglomeration of various inclusion particles on molten steel surface. ISIJ Int. 1997, 37, 946-955. [CrossRef]

27. Available online: https://www.imoa.info/molybdenum-uses/molybdenum-grade-alloy-steels-irons/heattreatable-engineering-steel.php (accessed on 8 April 2019).

28. Available online: https:/www.imoa.info/molybdenum-uses/molybdenum-grade-stainless-steels/ molybdenum-stainless-steels.php (accessed on 8 April 2019).

29. Gasik, M. Technology of Molybdenum Ferroalloys. In Handbook of Ferroalloy; Elsevier: Amsterdam, Nederland, 2013; pp. 387-396.

30. Available online: https://www.imoa.info/molybdenum-uses/molybdenum-grade-alloy-steels-irons/toolhigh-speed-steel.php (accessed on 8 April 2019).

31. Kong, J.H.; Zhen, L.; Guo, B.; Wang, A.H.; Xie, C.S. Influence of Mo content on microstructure and mechanical properties of high strength pipeline steel. Mater. Des. 2004, 25, 723-728.

32. Lindborg, U.; Torssell, K. A collision model for the growth and separation of deoxidation products. Trans. Metall. Soc. AIME 1968, 242, 94-102.

33. Kiessling, R.; Lange, N. Non-Metallic Inclusions in Steel: Part 1: Inclusions Belonging to the Pseudo-Ternary $\mathrm{MnO}-\mathrm{SiO}_{2}-\mathrm{Al}_{2} \mathrm{O}_{3}$ and Related System; The Metals Society: London, UK, 1968; pp. 17-25. 
34. Mao, H.H.; Fabrichnaya, O.; Selleby, M.; Sundman, B. Thermodynamic assessment of the $\mathrm{MgO}-\mathrm{Al}_{2} \mathrm{O}_{3}-\mathrm{SiO}_{2}$ system. J. Mater. Res. 2005, 20, 975-986. [CrossRef]

35. Wijk, O.; Brabie, V. The purity of ferrosilicon and its influence on inclusion cleanliness of steel. ISIJ Int. 1996, 36, 132-135. [CrossRef]

36. Reddy, R.G.; Chaubal, P.; Pistorius, P.C.; Pal, U. Advances in Molten Slags, Fluxes, and Salts. In Proceedings of the 10th International Conference on Molten Slags, Fluxes and Salts, Washington, DC, USA, 22-25 May 2016.

37. Bardelcik, A.; Salisbury, C.P.; Winkler, S.; Wells, M.A.; Worswick, M.J. Effect of cooling rate on the high strain rate properties of boron steel. Int. J. Impact Eng. 2010, 37, 694-702. [CrossRef]

38. Kapadia, B.M. Effect of boron additions on the toughness of heat-treated low-alloy steels. J. Heat Treat. 1987, 5, 41-53. [CrossRef]

39. Ghali, S.N.; Elfaramawy, H.S.; Eissa, M.M. Influence of boron additions on mechanical properties of carbon steel. J. Miner. Mater. Char. Eng. 2012, 11, 995-999. [CrossRef]

40. Zhuchkov, V.I.; Akberdin, A.A.; Vatolin, N.A.; Leont'ev, L.I.; Zayakin, O.V.; Kim, A.S.; Konurov, U.K. Application of boron-containing materials in metallurgy. Russ. Metall. 2011, 12, 1134-1137. [CrossRef]

41. Titova, T.I.; Shulgan, N.A.; Malykhina, I.Y. Effect of boron microalloying on the structure and hardenability of building steel. Met. Sci. Heat Treat. 2007, 49, 39-44. [CrossRef]

42. Polyakov, O. Boron Ferroalloys. In Handbook of Ferroalloy; Elsevier: Amsterdam, Nederland, 2013; pp. $449-457$.

43. Manashev, I.R.; Shatokhin, I.M.; Ziatdinov, M.K.; Bigeev, V.A. Microalloying of steel with boron and the development of ferrotitanium boride. Steel Transl. 2010, 39, 896-900. [CrossRef]

44. Mohrbacher, H. Principal Effects of Mo in HSLA Steels and Cross Effects with Microalloying Elements; International Seminar in Applications of Mo in Steels: Beijing, China, 2010.

45. Ferroalloys and Alloying Additives Online Handbook-Boron. Available online: https://amg-v.com/boronpage. html (accessed on 8 April 2019).

46. Zhang, L.F.; Taniguchi, S.; Cai, K.K. Fluid flow and inclusion removal in continuous casting tundish. Metall. Mater. Trans. B 2000, 31, 253-266. [CrossRef]

47. Zhang, L.F.; Pluschkell, W. Nucleation and growth kinetics of inclusions during liquid steel deoxidation. Ironmak. Steelmak. 2003, 30, 106-110. [CrossRef]

48. Brimacombe, J.K.; Kumar, S.; Hlady, C.O.; Samarasekera, I.V. The continuous casting of stainless steels. In INFACON 6, Proceedings of the 1st International Chromium Steel and Alloys Congress, Cape Town, South Africa, 8-11 March 1992; South African Inst. of Mining and Metallurgy: Johannesburg, South Africa, 1992; pp. 7-23.

49. Weise, J.; Lehmhus, D.; Baumeister, J.; Kun, R.; Bayoumi, M.; Busse, M. Production and properties of 316L stainless steel cellular materials and syntactic foams. Steel Res. Int. 2014, 85, 486-497. [CrossRef] 